\section{BIBLIOMETRIC STUDY OF SCIENTIFIC PRODUCTION ON HANDBALL}

\author{
ESTUDO BIBLIOMÉTRICO DA PRODUÇÃO CIENTÍFICA EM \\ HANDEBOL C P
}

\author{
ESTUDIO BIBLIOMÉTRICO DE LA PRODUCCIÓN CIENTÍFICA EN \\ BALONMANO C \\ doi' https://doi.org/10.22456/1982-8918.101908
}

(iD) Alberto Pardo Ibáñez* <alberto.pardo@uv.es>

(D) Joaquín Madera Gil* <joaquin.madera@uv.es>

(D) Maite Pellicer Chenoll*<mtepeche@uv.es>

*Universitat de Valencia. Valencia, Comunitat Valenciana, España.

\begin{abstract}
This study carries out a bibliometric analysis of the scientific production on handball with the following goals: (1) to characterize the publications; (2) to analyze productivity; (3) to identify topic areas and journals; and (4) to present the various co-occurrence networks. The analysis consisted of calculating basic bibliometric indicators, and co-occurrence analysis was carried out to establish the relationships between authors, between citations of scientific papers and between keywords chosen by authors. A total of 1,637 original papers and 90 reviews in 399 journals were analyzed; 4,752 authors signed papers related to handball. The main topics were 'handball' and 'ACL,' and a tendency towards increasing presence of papers from the training field was found in recent years.
\end{abstract}

Keywords: Bibliometrics. Sports. Review.
Received: $13-04-2020$

Accepted: 28-07-2020

Published: 19-09-2020

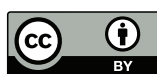

Este é um artigo publicado sob a licença Creative Commons Atribuição 4.0 Internacional (CC BY 4.0). eISSN: 1982-8918 


\section{INTRODUCTION}

Handball is a contact team sport that involves running, jumping, speed, and throwing (WALLACE; CARDINALE, 1997), in which interaction with colleagues and adversaries and the adjustment of space-time are fundamental to achieve an attack (score goal) or defense (avoid goal and recover the ball).

Handball was included as an Olympic sport in the 1972 Games in Munich. The International Handball Federation now includes the African Handball Confederation (53 member Federations), Asian Handball Federation (44 member Federations), European Handball Federation (52 member Federations), North America and the Caribbean Handball Confederation (21 member Federations), Oceania Continent Handball Federation (20 member Federations) and South and Central America Handball Confederation (19 member Federations). There is no exact data on the number of handball practitioners, but it is one of the most popular team sports all over the world, particularly in Europe (ACHENBACH et al., 2018).

It is difficult to describe the game and determine the factors that influence performance because there are many physical and technical-tactical individual demands, while the development and improvement of the game play is complex and multifactorial (WAGNER et al., 2014).

The players' innate characteristics, such as anthropometry, talent, physiology and neuromuscular factors have been mentioned as relevant in achieving high performance. In addition, the complex training process must include the correct interaction between bio-energy level (endurance), bio-relations (tactics) and biomechanics (technique). The efficiency level in this sport is influenced by psychological, mental, and sociological components (KILINÇ, 2008; SAAVEDRA et al., 2018). These objectives can be combined to train the handball player to attack, defend and to reach maximum performance, at least in two specific positions. Of course, the physical-technical demands of the game lead to injuries that should either be prevented or quickly remedied, from the performance point of view.

It is therefore interesting, and we think it is necessary, to know the recent trends, for example, in handball bibliometric studies

Bibliometric studies provide a global vision of research on thematic areas, journals, number of publications, productivity, authors, etc., as well as describing the evolution or regression of a particular thematic area (PRIETO; GOMEZ; SAMPAIO, 2015; VILLAMÓN et al., 2012) and it is a tool for building a scientific work structure (JOB, 2018). Sport is a modern social multidisciplinary phenomenon. This type of study makes it possible to detect the strengths and weaknesses of sports research and its evolution over time and gives an insight into recent research tendencies in this field.

The aim of the present study was thus to carry out a bibliometric analysis of the scientific production on handball. The main objectives were: (1) to characterize the publications (2) to analyze productivity, (3) to identify the topical areas and journals and (4) to present the different co-ocurrence networks. 


\section{MATERIAL AND METHODS}

\subsection{DATA SOURCE}

The search was made in the Web of Science Core Collection, which was accessed via WoS (Web of Science ${ }^{\circledR}$, Clarivate Analytics, Philadelphia, USA). The strategy employed was a basic search using the general term handball, which had been used previously in works on this subject (PRIETO; GOMEZ; SAMPAIO, 2015; SKEJ $\varnothing$ et al., 2019). Handball is a well used and accepted term around the world and exists in most of the languages present in the databases.

The study was limited to original research papers and reviews. Proceedings papers, meeting abstracts, book chapters, editorial material, corrections, book reviews, letters, notes, art exhibit reviews, news items, data papers, early access and poetry were all excluded.

The search was performed on July 10, 2019 and was limited to publications up to 2018 , inclusive. The initial search recovered 1735 articles. All the records were stored on a hard disk in plain text format for subsequent analysis.

\subsection{BIBLIOMETRIC ANALYSIS AND CONSTRUCTION OF A SCIENTIFIC AND CITATION NETWORK}

Initially we checked the articles to detect duplicated records. The authors' names were standardized, with attention to possible misspellings of names and initials. Other specific fields, such as "author address" were used to resolve synonymy or homonymy phenomena in the names (JENSEN; ROUQUIER; CROISSANT, 2009). When the WoS database did not provide the author's address (for some coauthors), an additional search was made on Google to clear up this question. When the authors specified more than one institution name, the latest was chosen.

Bibexcel software (version 2011-02-03; Olle Persson, Umeå University, Umeå, SWE) was used for the bibliometric analysis and to construct networks. The Pajek Program (version 1.28; Batagelj and Mrvar, University of Ljubljana, Ljubljana, Slovenia) was used to represent the scientific and citation networks obtained.

The analysis consisted of calculating basic bibliometric indicators and a cooccurrence analysis was carried out to establish the relationships between authors, between citations of scientific papers and between authors' keywords (AKs). To facilitate visualization and understanding of the networks, only those that achieved the minimum intensity between the relationships were incorporated into the study.

The calculated indicators were:

1. General data: Number of published articles, number of AKs and ratio AKs/paper, number of published documents per year, language, journals and categories in which they were published.

2. Analysis of productivity: number of authors, authors' productivity, collaboration index or average number of authors per document, most cited number of authors (Total Local Citation Score) and the most cited paper. 
3. Analysis of topical areas and the most representative journals: number of categories, the main categories in which handball works have been published and citation maps were generated, the journals with the most works and number of citations of the main journals that publish papers on handball.

4. Scientific and citation networks: relationships among authors was represented through maps (threshold $\geq 5$ papers). Only research groups with more than two members were represented and the centrality values occupied by the authors within these networks were calculated. A citation network among the articles was also created. A network represented papers with at least 40 cites.

5. Analysis of Author Keywords: a frequency analysis and co-ocurrences between the AKs (AK $\geq 5)$ were performed, together with a study of AKs dynamics in the last 10 years. For this, the term handball was excluded, as it had been used as the term in our search for documents.

\section{RESULTS}

\subsection{GENERAL DATA}

Our search in the Web of Science Core Collection database recovered 1735 papers, of which 8 were discarded because of duplication, so that 1637 original papers and 90 reviews remained for the study. The documents had a total of 7497 AKs, although the first document with AKs was published in 1991 (only 11 AKs were recovered in this year). The ratio AKs/documents was approximately 4.

The first original article on handball was indexed in this database in 1964 (BANISTER et al., 1964), although we found that most of the papers had been published in the last five years $(50.26 \%$ of the total). Most of these publications were written in English (88.07\%), followed by Spanish (4.75\%) and German (2.55\%), but there were also other languages, like Portuguese, French, Russian and Japanese, among others. All the papers were published in a total of 399 journals. Most of the papers were published in the Sports Science category (64\%), followed by Orthopedics (14.53\%) and Hospitality, Leisure, Sport \& Tourism (8.74\%). Figure 1 (next page) gives the number of scientific papers published since 1991.

\subsection{ANALYSIS OF PRODUCTIVITY, AUTHOR CITATIONS AND MOST CITED PAPERS}

A total of 4752 authors signed papers related to the term handball, with an average 3 authors per paper, while 38 produced $\geq 10$ papers. The five most productive authors in descending order were: Timothy E. Hewett, Roald Bahr, Grethe Myklebust, Gregory D. Myer and Roland Van den Tillaar.

Table 1 shows the most productive authors and the number of citations they received. The most frequently cited paper was by Olsen et al. (OLSEN et al., 2004), with a total of 550 cites. 
Figure 1- Number of articles and AKs published in handball from 1991 to 2018

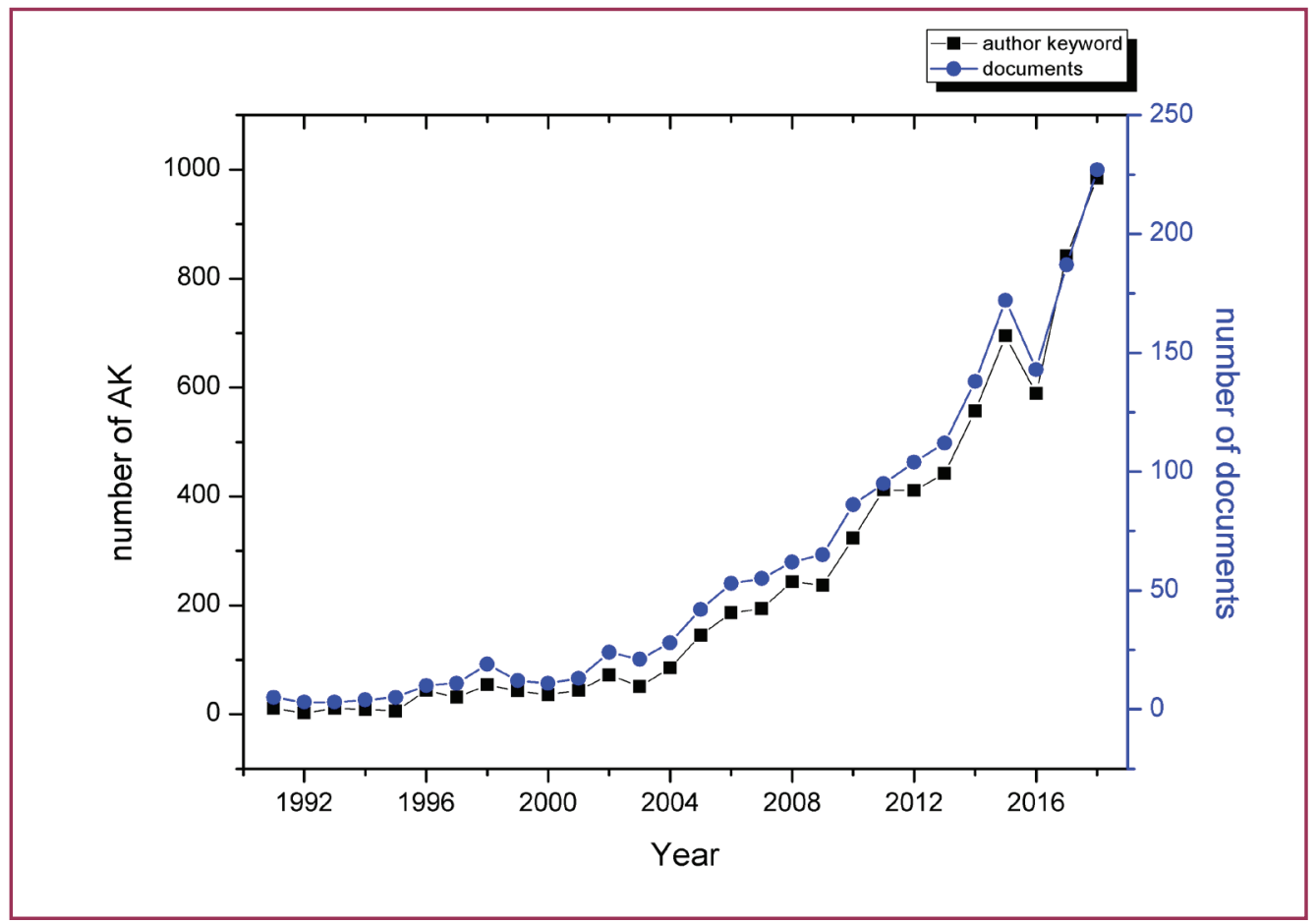

Source: prepared by authors

Table 1 - Most productive authors and cites received

\begin{tabular}{|c|c|c|c|c|c|}
\hline 1st Author & $\mathrm{n}^{\circ}$ papers & $\mathrm{n}^{\circ}$ cites & $\begin{array}{l}\text { cites/ } \\
\text { paper }\end{array}$ & $\begin{array}{l}\text { most cited paper } n^{\circ} \text { cites } \\
\text { (reference) }\end{array}$ & Institution \\
\hline Hewett TE & 51 & 4189 & 82,14 & 497(GRIFFIN et al., 2006) & Mayo Clin, Rochester, MN, USA \\
\hline Bahr R & 49 & 5442 & 111,06 & 449(MYKLEBUST, G. et al., 2003) & $\begin{array}{c}\text { Norwegian Sch Sport Sci, Oslo Sports Trauma Res Ctr, Dept Sports } \\
\text { Med, PB } 4014 \text { Ulleval Stad, N-0806 Oslo, Norway }\end{array}$ \\
\hline Myklebust G & 44 & 4595 & 104,43 & 449(MYKLEBUST, G. et al., 2003) & Norwegian Sch Sport Sci, Oslo Sports Trauma Res Ctr, Oslo, Norway \\
\hline Myer GD & 41 & 2744 & 66,93 & 374(HEWETT et al., 2006) & $\begin{array}{l}\text { Cincinnati Childrens Hosp Med Ctr, Div Sports Med, Cincinnati, OH } \\
45229 \text { USA }\end{array}$ \\
\hline $\begin{array}{l}\text { Van den Tillaar } \\
\text { R }\end{array}$ & 32 & 704 & 22,00 & 72(MARQUES et al., 2007) & Nord Univ, Dept Sports Sci, Levanger, Norway \\
\hline
\end{tabular}

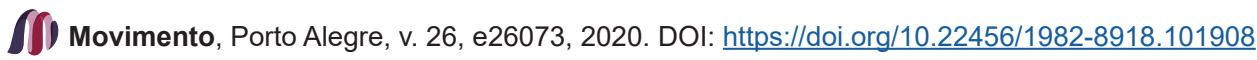




\begin{tabular}{|c|c|c|c|c|c|}
\hline Krosshaug $\mathrm{T}$ & 31 & 2092 & 67,48 & $\begin{array}{l}\text { 446(KROSSHAUG et al., 2007)4. } \\
\text { MethodsSix international experts } \\
\text { performed visual inspection } \\
\text { analyses of } 39 \text { videos ( } 17 \text { male and } \\
22 \text { female players }\end{array}$ & Norwegian Sch Sport Sci, Dept Sports Med, Oslo, Norway \\
\hline Engebretsen L & 27 & 4342 & 160,81 & 550(OLSEN et al., 2004) & $\begin{array}{c}\text { Norwegian Sch Sport Sci, Dept Sports Med, Oslo Sports Trauma Res } \\
\text { Ctr, PB } 4014 \text { Ullevaal Stad, N-0806 Oslo, Norway }\end{array}$ \\
\hline Ford KR & 25 & 1870 & 74,80 & 374(HEWETT et al., 2006) & High Point Univ, Sch HIth Sci, Dept Phys Therapy, High Point, NC USA \\
\hline Schwesig R & 18 & 49 & 2,72 & 12(FIESELER et al., 2015) & Martin Luther Univ Halle Wittenberg, Halle, Germany \\
\hline Chamari K & 17 & 272 & 16,00 & 80(CHAOUACHI et al., 2009) & $\begin{array}{c}\text { Qatar Orthopaed \& Sports Med Hosp, Athlete Hlth \& Performance Res } \\
\text { Ctr ASPETAR, Doha, Qatar }\end{array}$ \\
\hline Bencke J & 16 & 547 & 34,19 & 111(BENCKE et al., 2002) & $\begin{array}{l}\text { Copenhagen Univ Hosp Amager Hvidovre, Hvidovre Hosp, Dept } \\
\text { Orthoped Surg Sect 333, Human Movement Anal Lab Sect 247, } \\
\text { Copenhagen, Denmark }\end{array}$ \\
\hline Steffen K & 16 & 1021 & 63,81 & 262(SOLIGARD et al., 2009) & Oslo Sports Trauma Res Ctr, Oslo, Norway \\
\hline Fieseler G & 15 & 49 & 3,27 & 12(FIESELER et al., 2015) & Helios Clin, Div Shoulder Surg \& Sports Med, Warburg, Germany \\
\hline Aagaard P & 15 & 482 & 32,13 & $\begin{array}{l}\text { 103(ZEBIS et al., 2009) } \\
\text { identification of risk factors has high } \\
\text { clinical relevance in the prevention } \\
\text { of ACL rupture. Hypothesis } \\
\text { Noninjured athletes with low knee } \\
\text { flexor electromyography (EMG }\end{array}$ & $\begin{array}{l}\text { Univ Southern Denmark, Dept Sports Sci \& Clin Biomech, Res Unit } \\
\text { Muscle Physiol \& Biomech, Odense, Denmark }\end{array}$ \\
\hline Garrett WE & 15 & 1231 & 82,07 & 497(GRIFFIN et al., 2006) & Univ N Carolina, Greensboro, NC 27412 USA \\
\hline Shultz SJ & 14 & 863 & 61,64 & 497(GRIFFIN et al., 2006) & Paris Lodron Univ Salzburg, Salzburg, Austria \\
\hline Wagner $\mathrm{H}$ & 14 & 260 & 18,57 & $\begin{array}{l}\text { 45(WAGNER et al., 2011)the } \\
\text { players utilize various throwing } \\
\text { techniques that differ in the lower } \\
\text { body movements (with and without } \\
\text { run-up or jump }\end{array}$ & $\begin{array}{l}\text { Carl von Ossietzky Univ Oldenburg, Inst Sport Sci, Oldenburg, } \\
\text { Germany }\end{array}$ \\
\hline
\end{tabular}

Source: prepared by authors

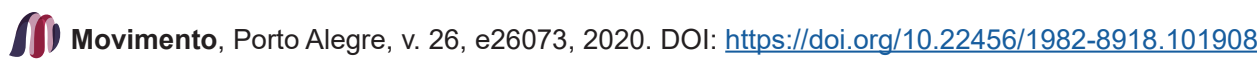




\subsection{ANALYSIS OF TOPICAL AREAS AND THE MOST REPRESENTATIVE JOURNALS}

As is well known, journals are usually indexed in more than one area at a time. Our analysis verified that the papers related to handball appeared in 84 categories, mostly in the Sport Sciences, Orthopedics and Hospitality, Leisure, and Sport \& Tourism categories. The map of category co-occurrence can be seen in Figure 2. The highest number of co-occurrences (178) was in Sport Sciences and Orthopedics.

Figure 2 - Co-occcurrence categories in which the journals are indexed with handball papers (threshold $\geq 5$ papers)

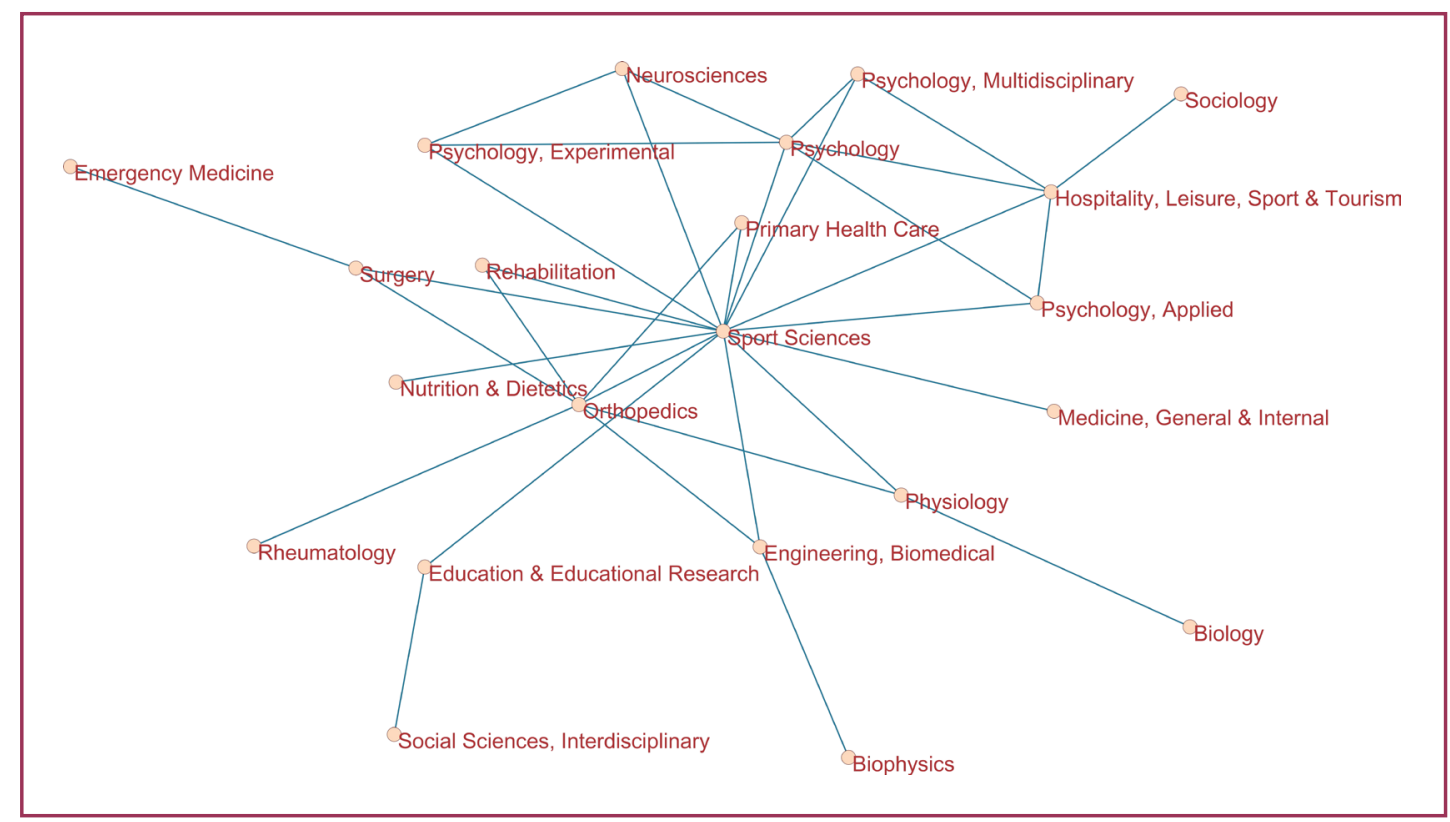

Source: prepared by authors

The three journals that published the most papers on handball were the Journal of Strength and Conditioning Research (104), the American Journal of Sports Medicine (69) and the Scandinavian Journal of Medicine \& Science in Sports (68). The three that received the most citations were the American Journal of Sports Medicine, British Journal of Sports Medicine and the Scandinavian Journal of Medicine \& Science in Sports. Table 2 (next page) shows the citation data by journal.

\subsection{SCIENTIFIC AND CITATION NETWORKS}

A network of co-authors was built to find the large research groups who worked together. For simplicity's sake, it was reduced to only co-authors who coincided in more than 5 papers, and only those groups with more than 2 members were included. The seven groups with most joint activity can be seen in Figure 3 (next page). Two groups with more than 12 members and another five groups with four or fewer stand out. 
Table 2 - Journals that received the highest number of citations

\begin{tabular}{|c|c|c|}
\hline ISSN & Journal & Cites \\
\hline ‘0363-5465’ & 'American Journal of Sports Medicine' & 5820 \\
\hline ‘0306-3674’ & 'British Journal of Sports Medicine' & 2627 \\
\hline ‘0905-7188’ & 'Scandinavian Journal of Medicine \& Science in Sports' & 2481 \\
\hline '1064-8011' & 'Journal of Strength and Conditioning Research' & 1635 \\
\hline ‘0112-1642’ & 'Sports' & 1542 \\
\hline ‘0112-1642’ & 'Sports Medicine' & 1464 \\
\hline ‘0195-9131’ & 'Medicine and Science in Sports and Exercise' & 1020 \\
\hline ‘0942-2056’ & ‘Knee' & 901 \\
\hline ‘0172-4622’ & 'International Journal of Sports Medicine' & 861 \\
\hline ‘0264-0414’ & 'Journal of Sports Sciences' & 860 \\
\hline '1050-642X’ & 'Clinical Journal of Sport Medicine' & 756 \\
\hline '0190-6011’ & 'Journal of Orthopaedic \& Sports Physical Therapy' & 745 \\
\hline ‘1439-6319’ & 'European Journal of Applied Physiology’ & 711 \\
\hline ‘0959-535X’ & 'British Medical Journal' & 603 \\
\hline ‘1062-6050’ & 'Journal of Athletic Training' & 524 \\
\hline ‘0942-2056’ & 'Knee Surgery Sports Traumatology Arthroscopy' & 475 \\
\hline ‘0022-4707’ & 'Journal of Sports Medicine and Physical Fitness' & 399 \\
\hline ‘0031-5125’ & 'Perceptual and Motor Skills' & 398 \\
\hline ‘1303-2968’ & 'Journal of Sports Science and Medicine' & 358 \\
\hline ‘0350-6134’ & 'Collegium Antropologicum' & 328 \\
\hline
\end{tabular}

Source: prepared by authors

Figure 3 - Network of co-authors (threshold $\geq 5$ papers; groups of more than 3 authors). The colors are those of the clusters calculated by the VOSviewer algorithm.

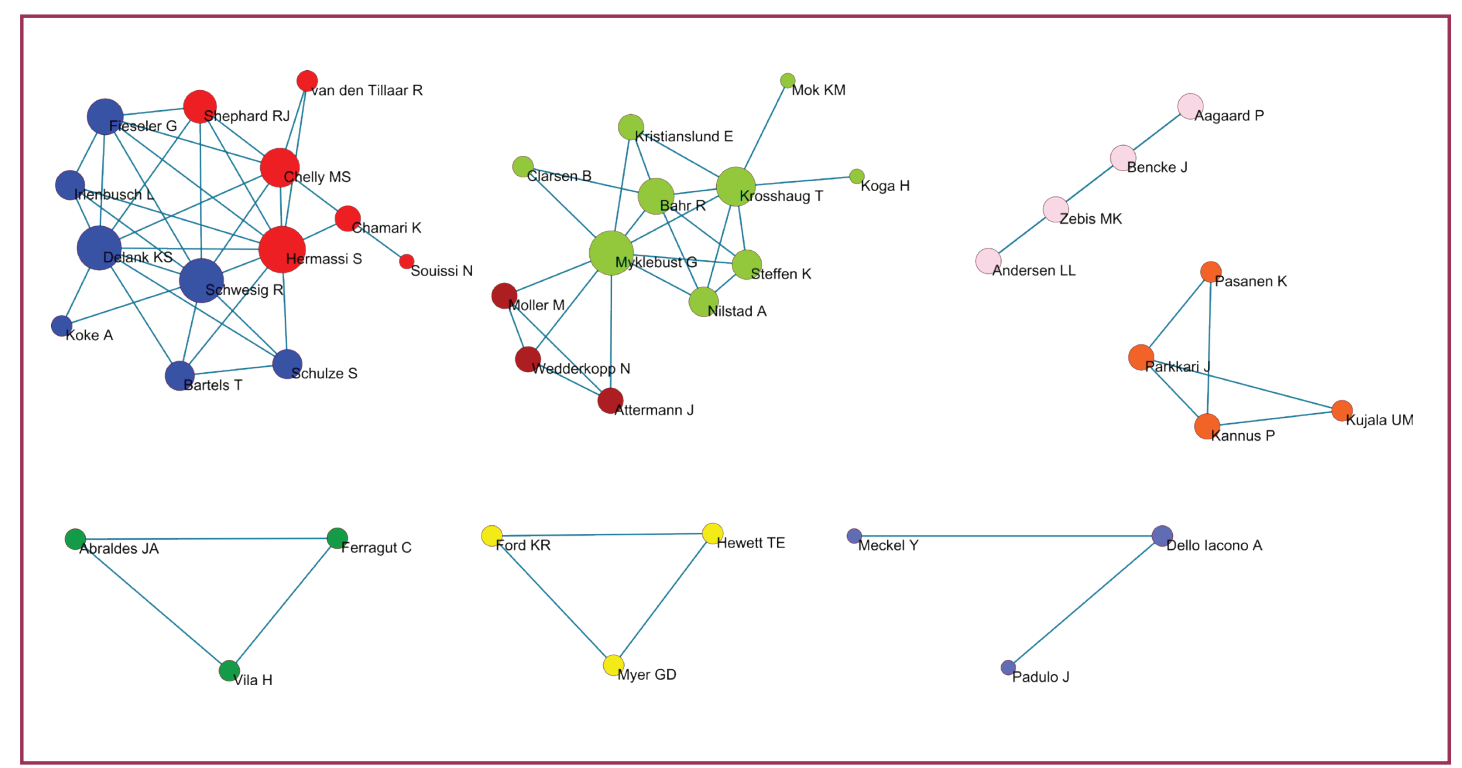

Source: prepared by authors 
The centrality values of each of the authors within these networks can be viewed in Table 3. Basically, it can be inferred that two people lead the most numerous clusters (i.e. Hermassi and Myklebust). The leadership in the rest of the groups is much more disperse.

Table 3 - Centrality values of the authors that make up the main co-author networks.

\begin{tabular}{|c|c|c|c|c|c|c|}
\hline Author & Degree & $\begin{array}{c}\text { Weighted } \\
\text { Degree }\end{array}$ & Closeness & Betweenness & $\begin{array}{l}\text { Average } \\
\text { Distance }\end{array}$ & $\begin{array}{c}\text { Proximity } \\
\text { Prestige }\end{array}$ \\
\hline Hermassi S & 10 & 89 & 0,1857 & 0,0121 & 1,1667 & 0,1743 \\
\hline Myklebust G & 9 & 81 & 0,1692 & 0,0162 & 1,1818 & 0,1578 \\
\hline Bahr R & 6 & 79 & 0,1375 & 0,0021 & 1,4545 & 0,1282 \\
\hline Schwesig R & 9 & 76 & 0,1625 & 0,0048 & 1,3333 & 0,1525 \\
\hline Delank KS & 9 & 70 & 0,1625 & 0,0048 & 1,3333 & 0,1525 \\
\hline Krosshaug T & 7 & 64 & 0,1467 & 0,0115 & 1,3636 & 0,1367 \\
\hline Fieseler G & 6 & 59 & 0,1368 & 0,0003 & 1,5833 & 0,1285 \\
\hline Chelly MS & 7 & 57 & 0,1529 & 0,0050 & 1,4167 & 0,1436 \\
\hline Hewett TE & 2 & 56 & 0,0500 & 0,0000 & 1,0000 & 0,0339 \\
\hline Myer GD & 2 & 56 & 0,0500 & 0,0000 & 1,0000 & 0,0339 \\
\hline Ford KR & 2 & 42 & 0,0500 & 0,0000 & 1,0000 & 0,0339 \\
\hline Shephard RJ & 5 & 41 & 0,1300 & 0,0000 & 1,6667 & 0,1220 \\
\hline Steffen K & 4 & 34 & 0,1222 & 0,0000 & 1,6364 & 0,1139 \\
\hline Irlenbusch L & 4 & 28 & 0,1238 & 0,0000 & 1,7500 & 0,1162 \\
\hline Nilstad A & 4 & 27 & 0,1222 & 0,0000 & 1,6364 & 0,1139 \\
\hline Bencke J & 3 & 25 & 0,0667 & 0,0000 & 1,0000 & 0,0508 \\
\hline Zebis MK & 3 & 25 & 0,0667 & 0,0000 & 1,0000 & 0,0508 \\
\hline Kristianslund E & 3 & 23 & 0,1158 & 0,0000 & 1,7273 & 0,1079 \\
\hline Parkkari J & 3 & 21 & 0,0667 & 0,0003 & 1,0000 & 0,0508 \\
\hline Schulze S & 4 & 20 & 0,1238 & 0,0000 & 1,7500 & 0,1162 \\
\hline Bartels T & 4 & 20 & 0,1238 & 0,0000 & 1,7500 & 0,1162 \\
\hline Kannus P & 3 & 20 & 0,0667 & 0,0003 & 1,0000 & 0,0508 \\
\hline Andersen LL & 3 & 20 & 0,0667 & 0,0000 & 1,0000 & 0,0508 \\
\hline Aagaard P & 3 & 20 & 0,0667 & 0,0000 & 1,0000 & 0,0508 \\
\hline Chamari K & 3 & 17 & 0,1182 & 0,0064 & 1,8333 & 0,1109 \\
\hline Moller M & 3 & 15 & 0,1048 & 0,0000 & 1,9091 & 0,0977 \\
\hline Attermann $\mathrm{J}$ & 3 & 15 & 0,1048 & 0,0000 & 1,9091 & 0,0977 \\
\hline Wedderkopp N & 3 & 15 & 0,1048 & 0,0000 & 1,9091 & 0,0977 \\
\hline
\end{tabular}

Source: prepared by authors

Figure 4 shows the citation network among the papers studied with at least 40 cites. It can be seen that there are four major citation centers, each with two 
widely referenced papers. There seem to be two main themes: a) specific handball training and performance (green and red cluster), b) prevention and injury, mainly the relationship of collective sports with injuries (handball, soccer, football, basketball, etc.) and the focus on anterior cruciate ligament (ACL) injuries (yellow and blue cluster). It should be emphasized that the citation relationships are between the papers in each group.

Figure 4 - Citation network among articles published on handball (threshold $\geq 40$ cites).

The colors are those of the clusters calculated with the VOSviewer algorithm.

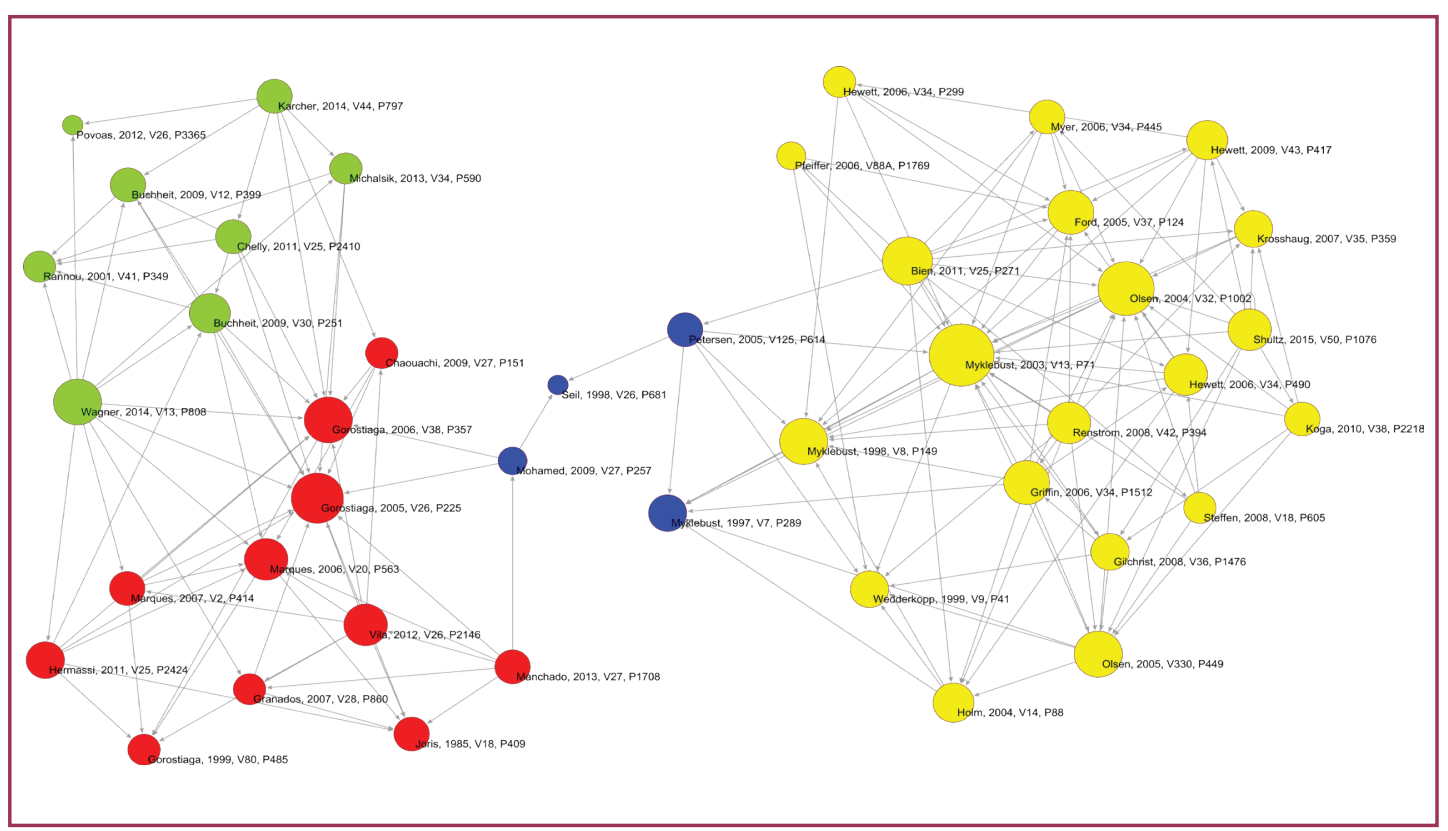

Source: prepared by authors

\subsection{ANALYSIS OF AUTHOR KEYWORDS}

Some terms were normalized to analyze the AKs (words with the same meaning, plurals or acronyms) and a total of 3199 AKs were obtained. The five most often used words are: 'handball' (251 times), followed by 'ACL' (124), Sport (107), 'Team Sport' (89) and 'Biomechanics' (57). Table 4 (next page) shows the 40 most frequently used author keywords.

The words were analyzed to draw up the network of co-occurrences and clusters were generated. In general, we observed two major topics: "handball" and "ACL". The "Handball" group was composed of different AKs groups, including "team sport", "kinematics" and another group with names of sports. The other topic was developed around the term ACL and was composed of several clusters such as "injury prevention" and "biomechanics". The keywords with the highest frequency represent each cluster. Figure 5 (next page) shows the terms with the highest cooccurrence frequencies. 
Table 4 - Main keywords used in handball articles

\begin{tabular}{|c|c|c|c|}
\hline Author Keyword & Freq & Author Keyword & Freq \\
\hline HANDBALL & 251 & HEART RATE & 25 \\
\hline $\mathrm{ACL}^{*}$ & 124 & SHOULDER & 25 \\
\hline SPORT* & 107 & ANTHROPOMETRY & 24 \\
\hline TEAM SPORT* & 89 & BODY COMPOSITION & 24 \\
\hline BIOMECHANICS & 57 & MUSCLE STRENGTH & 24 \\
\hline INJURY PREVENTION & 51 & BASKETBALL & 22 \\
\hline PERFORMANCE & 50 & VOLLEYBALL & 22 \\
\hline TEAM HANDBALL & 46 & ACL INJURY & 22 \\
\hline ATHLETES & 45 & PHYSICAL EDUCATION & 21 \\
\hline KNEE & 44 & GENDER & 21 \\
\hline PREVENTION & 40 & HANDBALL PLAYER* & 19 \\
\hline TRAINING & 39 & AGILITY & 18 \\
\hline KINEMATICS & 35 & POWER & 18 \\
\hline STRENGTH & 35 & ATHLETIC PERFORMANCE & 18 \\
\hline INJURY & 33 & FATIGUE & 18 \\
\hline EXERCISE & 32 & ATHLETIC INJURIES & 17 \\
\hline FOOTBALL & 28 & EXPERTISE & 17 \\
\hline EPIDEMIOLOGY & 28 & STRENGTH TRAINING & 16 \\
\hline FEMALE & 27 & GOALKEEPER & 16 \\
\hline SOCCER & 26 & INJURY MECHANISM & 16 \\
\hline
\end{tabular}

Source: prepared by authors

Figure 5 - Networks identified from the cross analysis of AKs co-occurrences AKs (threshold $\geq 5$ co-words).

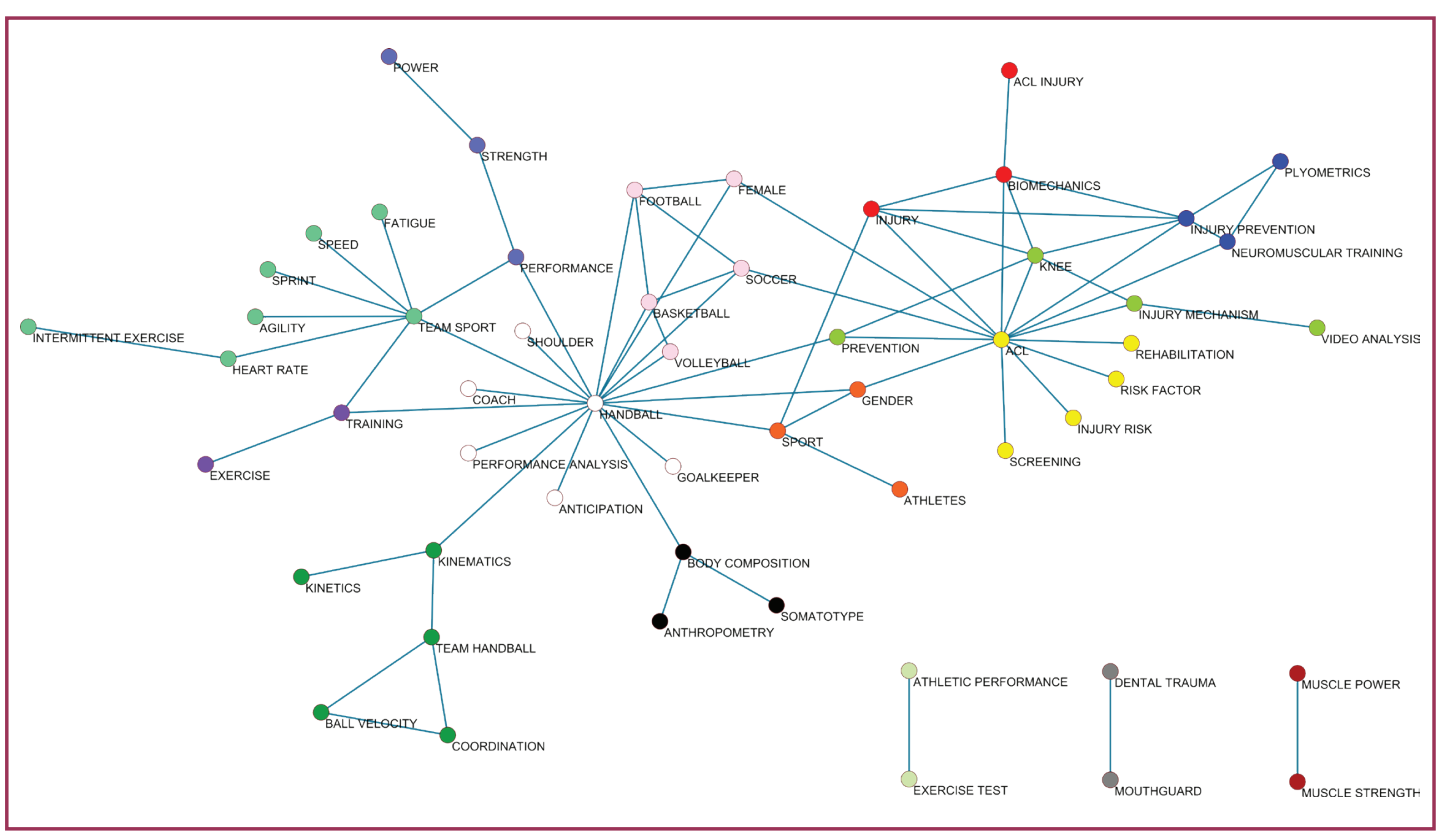


The dynamics of the key words used in the last ten years are shown in Figure 6. The term handball was eliminated because it was employed in our search. ACL appears as the most frequently used word. The presence of terms related to training topics has increased in the last two years (performance, team sport and sport).

Figure 6 - Dynamics of AKs used in handball papers from 2009 to 2018.

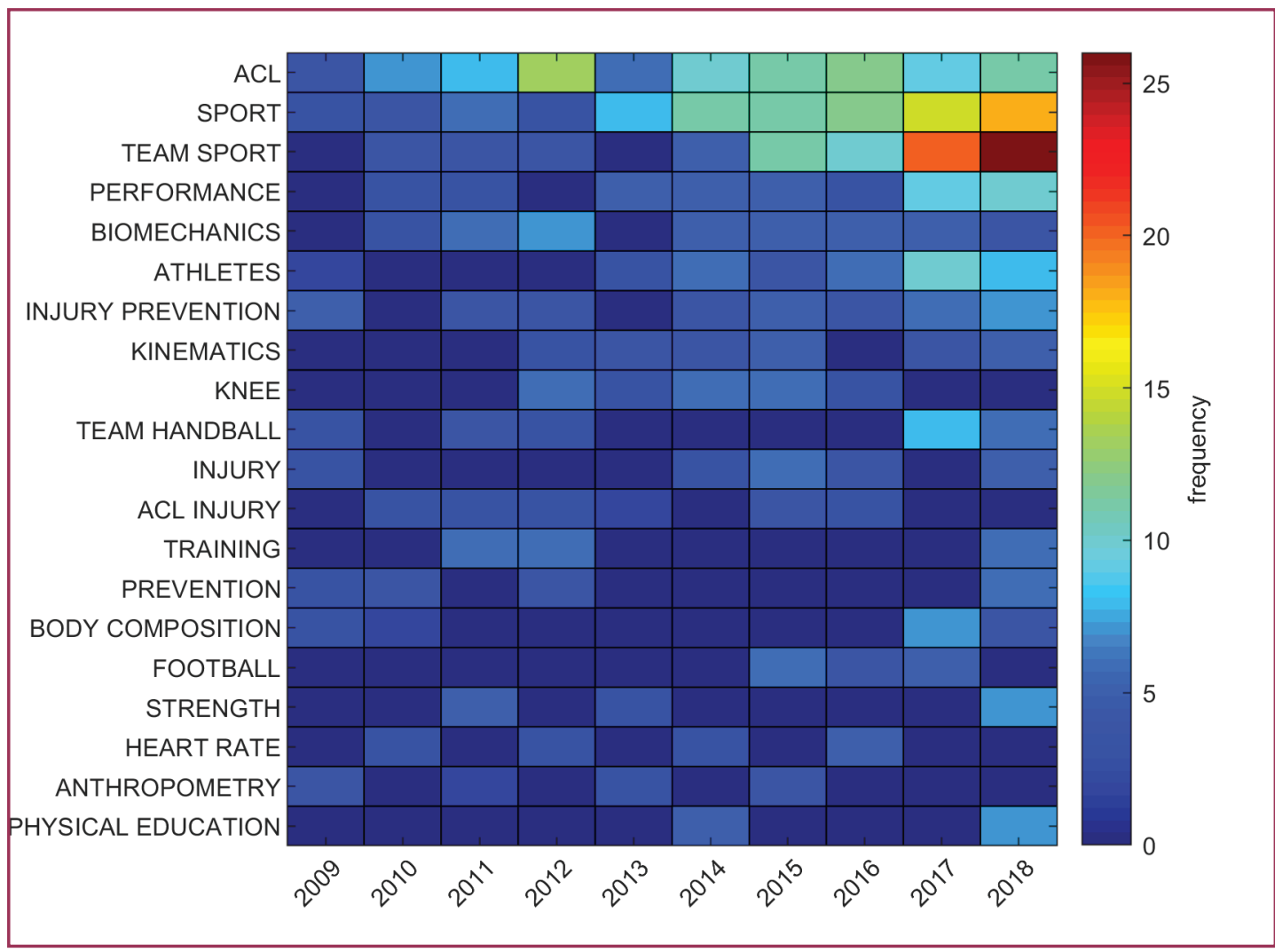

Source: prepared by authors

\section{DISCUSSION}

This study identified and analyzed scientific research on handball collaboration by integrating bibliometric analysis with the analysis of social networks. Its main contribution is that it clarifies the networks of co-occurrence among categories, authors, citations between the articles considered and identifies the dynamics of keywords in time in the scientific field related to handball. It also contributes a methodological novelty with respect to previous studies on sports bibliometry in that it analyzes AKs networks and dynamics, which has never been done before in handball studies.

This work is the first to use a more extensive search using the topic field, which allowed us to find a larger number of works and to recognize two main topics in handball studies: the first related to aspects of prevention and injuries (ACL on many occasions) and the second to sports performance.

The discussion is structured into two parts to highlight the most important aspects of our work: the first focuses on aspects of productivity and the second on the main contents of productivity. 
Regarding productivity, the progression of publications on handball was slow and intermittent from 1965 to 1990 . Since 1990 the number of publications has slowly increased, especially from 2000 until the present time. The same behavior was found in previous works on handball and other sports (CHIROSA RÍOS; MARTIN; OLMOS, 2013; PESET MANCEBO et al., 2013; PRIETO; GÓMEZ; SAMPAIO, 2015) and in the area of knowledge of Physical Activity and Sport Sciences (BLANCATORRES et al., 2019).

One of the possible reasons for the increased interest of scientific literature on handball research in recent years is probably the sport's social and economic relevance, together with its multidisciplinary character.

As in other areas, most papers were written in English (MARTIN et al., 2013; MORALES et al., 2017; PEREZ-GUTIERREZ et al., 2015). The leading international scientific databases use English as the main academic language.

Among the most prolific authors, the first places are occupied by those who focused on the field of medicine. Van der Tillaar had the largest number of publications on the study of performance aspects in handball and is ranked as fifth in the production of papers in this field. Until very recently, the sports science field was not of much interest for researchers (TSIGILIS et al., 2010) and most of the contributions focused on medical aspects (i.e. injuries), as has been found in other studies in sport with respect to contributions from the field of medicine (BLANCATORRES et al., 2019; CHIROSA RÍOS; MARTIN; OLMOS, 2013; GONZÁLEZ et al., 2018; PRIETO; GÓMEZ; SAMPAIO, 2015). However, there has been a notable increase in the number of authors who wrote papers about handball in the last two decades, as has been pointed out by Prieto, Gómez and Sampaio (2015). In addition, in agreement with other authors (BAKER; ROBERTSON-WILSON; SEDGWICK, 2003; CHIROSA RÍOS; MARTIN; OLMOS, 2013), we found that many authors only contributed one article (77.2\%) and very few contributed $\geq 10$ articles $(0.8 \%)$.

Of the 7 groups studied, we highlight two with a large number of components. Hermassi, leads one of these whose professional activity involves the field of training (performance), while the other group is led by Myklebust, and focuses on the field of medicine (injuries). Another notable group is that composed by Hewett, Myer and Ford, which has a high productivity in spite of being quite small.

With regard to journals, there are no specific handball or collective sports journals indexed in the WoS. The Journal Strength and Conditioning Research, American Journal of Sports Medicine and Scandinavian Journal of Medicine \& Science in Sports have published most articles on handball topics. These journals have also been cited in other studies as a reference for the volume of publications on this type of sports papers ( CHIROSA RÍOS; MARTIN; OLMOS, 2013; PALAZÓN; ORTEGA; GARCÍA-ANGULO, 2015; PEREZ-GUTIERREZ et al., 2015; PRIETO; GÓMEZ; SAMPAIO, 2015).

The AKs helped us to identify the development of the study contents. Apart from handball, the most frequently used words were ' $A C L$ ', 'sport' and 'team sport'. It is interesting that the most frequently used word $(A C L)$ is a term from medicine and is related to terms like prevention injury, injury, knee or rehabilitation. 
$A C L$ is one of the most serious knee injuries for team sport athletes and puts the player out of action for a long period of time (NAGELLI; HEWETT, 2017). There are many studies on the prevention of injuries in handball (BHAT; SREEDHAR, 2019; MYKLEBUST et al., 2002; MYKLEBUST; STEFFEN, 2015). As already mentioned, medical publications occupy an important place within the works that compose our sample, and injuries have received a great deal of attention in academic research on handball.

'Team sport' is another important term, although its coexistence with other expressions has been related to physical qualities (speed, ability, coordination, etc.) and physiological aspects (fatigue, heart rate), but it suffers from a lack of tactical work, an aspect of great importance in this type of sport. The complexity of this type of study in collective sports, i.e. identifying and characterizing the specific details of team-members' interactions during a match, is one of the main reasons pointed out (BARTLETT et al., 2012). Researchers have recently applied more sophisticated statistical procedures to data sets to study the effect of tactics in other collective sports by mean of network analysis (CLEMENTE; MARTINS; MENDES, 2016), temporal-pattern analysis (SARMENTO et al., 2014) and multiple logistic regression (LAGO-BALLESTEROS; LAGO-PEÑAS; REY, 2012).

The term 'biomechanics' refers to aspects of sports technique. However this word was found in this study to be related to medical terms, such as injury (STEPHENSON et al., 2018), ACL injury (ZEBIS; BENCKE, 2018), and injury prevention (KAJIWARA et al., 2019) among others. There are also studies that focus on performance (TILLAAR; ETTEMA, 2007; WAGNER et al., 2012), but their productivity is lower than that of biomechanics in the field of handball injuries.

Over the years, a few papers have focused their research interests on keyword dynamics (LEE, 2016). Word dynamics generally help us to clarify the evolution and shift in time of the papers' contents.

We also found a tendency in the last three years to increase the presence of words from the field of training, such as sport, team sport and performance. This now seems important because it may be necessary to increase the number of specific papers on handball tactics and technique. Research in this field is usually carried out in complex environments, but further studies of this type are required to improve the knowledge available on team sports like handball.

The main limitation of this study is that it only used a single database, the WoS Core Collection. Although the WoS is one of the most widely accepted scientific products in the field of research, additional databases would have increased the sample size of our research. Likewise, the search strategy used, in which only the term handball was introduced, could represent another limitation. Finally, we used the AKs to analyze the topics, and did not take into account other fields such as the titles or abstract. Future studies should explore these fields to examine the main themes. The currently available technology does not allow us to use complete texts or abstracts. In addition, for obvious reasons this paper does not include lessercited authors or words. However, we must consider that sometimes low frequencies at present may allow important advances in the near future. 


\section{CONCLUSIONS}

Although there is a multidisciplinary focus of interest in studies on handball, in this study we noted two main thematic areas: i.e. the improvement of performance and the prevention and rehabilitation of injuries. Regarding the author's collaboration, there are two large research groups which provide the greatest number of contributions. These two groups are linked to the medical area. Studies on specific handball performance are on the increase in the field of science. We believe that technological advances have made it easier to study performance in this complex sport. More research is needed on technical and tactical situations, performance and training effect analysis following an integrated and applied perspective.

The main limitation of this study is that a single database was used to collect the information, so the number of recovered items may have been reduced.

\section{REFERENCES}

ACHENBACH, Leonard et al. Neuromuscular exercises prevent severe knee injury in adolescent team handball players. Knee Surgery, Sports Traumatology, Arthroscopy, v. 26, n. 7, p. 1901-1908, 2018.

BAKER, Joseph; ROBERTSON-WILSON, Jennifer; SEDGWICK, Whitney. Publishing Productivity in Sport Psychology 1970-2000: An Exploratory Examination of the Lotka-Price Law. Journal of Sport and Exercise Psychology, v. 25, n. 4, p. 477-483, 2003.

BANISTER, E. W. et al. The Caloric Cost of Playing Handball. Research Quarterly. American Association for Health, Physical Education and Recreation, v. 35, n. 3, p. 236-240, 1964.

BARTLETT, Roger et al. Analysing Team Coordination Patterns from Player Movement Trajectories in Soccer: Methodological Considerations. International Journal of Performance Analysis in Sport, v. 12, n. 2, p. 398-424, 2012.

BENCKE, J. et al. Anaerobic power and muscle strength characteristics of 11 years old elite and non-elite boys and girls from gymnastics, team handball, tennis and swimming. Scandinavian Journal of Medicine \& Science in Sports, v. 12, n. 3, p. 171-178, 2002.

BHAT, Naseer Ahmad; SREEDHAR, K. Impact of an exercise training protocol on selected balance flexibility and injury prevalence among basketball and handball players. International Journal of Physiology, Nutrition and Physical Education, v. 4, n. 1, p. 548-552, 2019.

BLANCA-TORRES, Juan Carlos et al. Bibliometric analysis of scientific production in badminton. Journal of Human Sport and Exercise, v. 15, n. 2, p. 267-282, 2019. Disponível em: http://rua.ua.es/dspace/handle/10045/92588. Acesso em: 15 ago. 2019.

CHAOUACHI, Anis et al. Anthropometric, physiological and performance characteristics of elite team-handball players. Journal of Sports Sciences, v. 27, n. 2, p. 151-157, 2009.

CHIROSA RÍOS, Luis; MARTIN, Ignacio; OLMOS, Jesus. Bibliometric study (1922-2009) on rugby articles in research journals. South African Journal for Research in Sport, Physical Education and Recreation, v. 35, p. 105-109, 2013. 
CLEMENTE, Filipe; MARTINS, Fernando; MENDES, Rui. Analysis of scored and conceded goals by a football team throughout a season: A network analysis. Kinesiology, v. 48, p. 103-114, 2016.

FIESELER, G. et al. Intrarater reliability of goniometry and hand-held dynamometry for shoulder and elbow examinations in female team handball athletes and asymptomatic volunteers. Archives of orthopaedic and trauma surgery, v. 135, n. 12, p. 1719-1726, 2015.

GONZÁLEZ, Luis-Millán et al. An author keyword analysis for mapping Sport Sciences. PLoS ONE, v. 13, n. 8, p. e0201435, 2018.

GRIFFIN, Letha Y. et al. Understanding and Preventing Noncontact Anterior Cruciate Ligament Injuries: A Review of the Hunt Valley II Meeting, January 2005. The American Journal of Sports Medicine, v. 34, n. 9, p. 1512-1532, 2006.

HEWETT, Timothy E.; MYER, Gregory D.; FORD, Kevin R. Anterior Cruciate Ligament Injuries in Female Athletes: Part 1, Mechanisms and Risk Factors. The American Journal of Sports Medicine, v. 34, n. 2, p. 299-311, 2006.

JENSEN, Pablo; ROUQUIER, Jean-Baptiste; CROISSANT, Yves. Testing bibliometric indicators by their prediction of scientists promotions. Scientometrics, v. 78, n. 3, p. 467479, 2009.

JOB, Ivone. Bibliometria aplicada aos estudos do campo da Educação Física: confiabilidade, qualidade e relevância nas publicações. Motrivivência, v. 30, n. 54, p. 18-34, 2018.

KAJIWARA, Masaya et al. Knee biomechanics changes under dual task during single-leg drop landing. Journal of Experimental Orthopaedics, v. 6, n. 1, p. 5, 2019.

KILINÇ, Fatih. An Intensive Combined Training Program Modulates Physical, Physiological, Biomotoric, and Technical Parameters in Women Basketball Players. The Journal of Strength \& Conditioning Research, v. 22, n. 6, p. 1769 - 1778, 2008.

KROSSHAUG, Tron et al. Mechanisms of Anterior Cruciate Ligament Injury in Basketball: Video Analysis of 39 Cases. The American Journal of Sports Medicine, v. 35, n. 3, p. 359-367, 2007.

LAGO-BALLESTEROS, Joaquin; LAGO-PEÑAS, Carlos; REY, Ezequiel. The effect of playing tactics and situational variables on achieving score-box possessions in a professional soccer team. Journal of Sports Sciences, v. 30, n. 14, p. 1455-1461, 2012.

LEE, Seongsin. A Study on Research Trends in Public Library Research in Korea Using Keyword Networks. Libri, v. 66, n. 4, p. 263-274, 2016.

MARQUES, Mário C. et al. Relationship Between Throwing Velocity, Muscle Power, and Bar Velocity During Bench Press in Elite Handball Players. International Journal of Sports Physiology and Performance, v. 2, n. 4, p. 414-422, 2007.

MARTIN, Ignacio et al. Bibliometric study (1922-2009) on rugby articles in research journals. South African Journal for Research in Sport, Physical Education and Recreation, v. 35, n. 1, p. 105-119, 2013.

MORALES, Ángela et al. Análisis bibliométrico de la producción científica en Educación Musical en España / Bibliometric analysis of academic output in music education in Spain. Revista Española de Pedagogía, v. 75, n. 268, p. 399-414, 2017. 
MYKLEBUST, Grethe et al. Prevention of anterior cruciate ligament injuries in female team handball players: a prospective intervention study over three seasons. Scandinavian Journal of Medicine \& Science in Sports, v. 13, n. 4, p. 272-272, 2003.

MYKLEBUST, Grethe et al. Prevention of ACL injuries in female team handball players: a prospective intervention study. Medicine and Science in Sports and Exercise, v. 34, n. 5, p. S156, May 2002.

MYKLEBUST, Grethe; STEFFEN, Kathrin. Anterior Cruciate Ligament Injuries: Prevention Strategies. In: DORAL, M. N.; KARLSSON, J. (eds.). Sports Injuries: Prevention, Diagnosis, Treatment and Rehabilitation. Berlin, Heidelberg, 2015. p. 1357-1367. Disponível em: https://doi.org/10.1007/978-3-642-36569-0 82. Acesso em: 17 ago 2019.

NAGELLI, Christopher V.; HEWETT, Timothy E. Should Return to Sport be Delayed Until 2 Years After Anterior Cruciate Ligament Reconstruction? Biological and Functional Considerations. Sports Medicine, v. 47, n. 2, p. 221-232, 2017.

OLSEN, Odd-Egil et al. Injury Mechanisms for Anterior Cruciate Ligament Injuries in Team Handball: A Systematic Video Analysis. The American Journal of Sports Medicine, v. 32, n. 4, p. 1002-1012, 2004.

PALAZÓN, M. A.; ORTEGA, E.; GARCÍA-ANGULO, A. Análisis bibliométrico de la producción científica en el fútbol sala. SPORT TK-Revista EuroAmericana de Ciencias del Deporte, v. 4, n. 2, p. 19-24, 2015.

PEREZ-GUTIERREZ, Mikel et al. Bibliometric analysis of taekwondo articles published in the Web of Science (1989-2013). Ido Movement for Culture. Journal of Martial Arts Anthropology, v. 3, n. 15, p. 27-34, 2015.

PESET MANCEBO, Fernanda et al. Scientific literature analysis of Judo in Web of Science $囚$. Archives Of Budo - Science of Martial Arts, v.9, n. 2, p. 81-91, 2013. Disponível em: http:// roderic.uv.es/handle/10550/35088. Acesso em: 14 ago. 2019.

PRIETO, Jaime; GÓMEZ, Miguel-Ángel; SAMPAIO, Jaime. A bibliometric review of the scientific production in handball. Cuadernos de Psicología del Deporte, v. 15, n. 3, p. 145-154, 2015.

SAAVEDRA, Jose M. et al. Anthropometric Characteristics, Physical Fitness, and Throwing Velocity in Elite women's Handball Teams. The Journal of Strength \& Conditioning Research, v. 32, n. 8, p. 2294 - 2301, 2018.

SARMENTO, Hugo et al. Patterns of Play in the Counterattack of Elite Football Teams - A Mixed Method Approach. International Journal of Performance Analysis in Sport, v. 14, n. 2, p. 411-427, 2014.

SCHORER, J. et al. Influence of early environmental constraints on achievement motivation in talented young handball players. International Journal of Sport Psychology, v. 41, n. 1 , p. 42-57, 2010.

SKEJØ, Sebastian D. et al. Shoulder kinematics and kinetics of team handball throwing: A scoping review. Human movement science, v. 64, p. 203-212, 2019.

SOLIGARD, Torbjørn et al. Comprehensive Warm-up Programme to Prevent Injuries in Young Female Footballers: Cluster Randomised Controlled Trial. British Medical Journal, v. 338, n. 7686, p. 95-99, 2009.

STEPHENSON, Mitchell L. et al. Effects of timing of signal indicating jump directions on knee biomechanics in jump-landing-jump tasks. Sports Biomechanics, v. 17, n. 1, p. 67-82, 2018. 
TILLAAR, Roland Van Den; ETTEMA, Gertjan J. C. A Three-Dimensional Analysis of Overarm Throwing in Experienced Handball Players. Journal of applied biomechanics, $v$. 23, n. 1, p. 12-19, 2007.

TSIGILIS, Nikolaos et al. Impact factors of the sport sciences journals: Current trends, relative positions, and temporal stability. European Journal of Sport Science, v. 10, n. 2, p. 81-90, 2010.

VILLAMÓN, Miguel; JOB, Ivone; VALENCIANO VALCÁRCEL, Javier; DEVIIS-DEVÍS, José. Estudio comparativo de cinco revistas de Ciencias del Deporte indizadas en WoS. Revista de psicología del deporte, v. 21, n. 2, p. 281-287, 2012.

WAGNER, Herbert et al. Individual and Team Performance in Team-Handball: A Review. Journal of Sports Science \& Medicine, v. 13, n. 4, p. 808-816, 2014.

WAGNER, Herbert et al. Movement variability and skill level of various throwing techniques. Human Movement Science, v. 31, n. 1, p. 78-90, 2012.

WAGNER, Herbert et al. Performance and kinematics of various throwing techniques in team-handball. Journal of Sports Science \& Medicine, v. 10, n. 1, p. 73-80, 2011.

WALLACE, M. Brian; CARDINALE, Marco. Conditioning for Team Handball. Strength \& Conditioning Journal, v. 19, n. 6, p. 7 - 12, 1997.

ZEBIS, Mette K. et al. Identification of athletes at future risk of anterior cruciate ligament ruptures by neuromuscular screening. The American Journal of Sports Medicine, v. 37, n. 10, p. 1967-1973, 2009.

ZEBIS, Mette K.; BENCKE, Jesper. Biomechanical Aspects in Handball: Lower Limb. In: LAVER, L. et al. (eds.). Handball Sports Medicine: Basic Science, Injury Management and Return to Sport. Berlin, Heidelberg: Springer, 2018. p. 61-68. 
Resumo: O objetivo deste estudo foi realizar uma análise bibliométrica da produção científica do handebol com estes objetivos: (1) caracterizar as publicações, (2) analisar a produtividade, (3) identificar as áreas temáticas e as revistas de pesquisa e (4) apresentar as diferentes redes de co-ocorrência. A análise consistiu no cálculo de indicadores bibliométricos básicos e foi realizada uma análise de co-ocorrência para estabelecer as relações entre autores, entre citações de artigos científicos e entre palavras-chave de autores. Foram analisados 1.637 artigos originais e 90 revisões em 399 revistas. Um total de 4.752 autores assinaram artigos relacionados ao termo handebol. Os principais tópicos foram "handball" e "ACL", e encontramos uma tendência nos últimos anos em aumentar a presença de artigos da área de treinamento.

Palavras chave: Bibliometria. Desporto. Revisão.

Resumen: El objetivo de este estudio fue realizar un análisis bibliométrico de la producción científica sobre el balonmano con los siguientes objetivos: (1) caracterizar las publicaciones, (2) analizar la productividad, (3) identificar las áreas temáticas y las revistas y (4) presentar las diferentes redes de coocurrencia. EI análisis consistió en el cálculo de indicadores bibliométricos básicos y se realizó un análisis de coocurrencia para establecer las relaciones entre autores, entre citas de artículos científicos y entre palabras clave de los autores. Se analizaron 1637 artículos originales y 90 revisiones en 399 revistas. Un total de 4752 autores firmaron trabajos relacionados con el término balonmano. Los temas principales fueron "handball" y "ACL" y, en los últimos años, hemos encontrado una tendencia de aumento en la presencia de trabajos del ámbito del entrenamiento.

Palabras clave: Bibliometría. Deporte. Revisión. 


\section{USE LICENSE}

This is an article published in open access under the Creative Commons Attribution 4.0 International (CC BY 4.0), which allows use, distribution and reproduction in any medium, as long as the original work is correctly cited. More information at: http:// creativecommons.org/licenses/by/4.0

\section{CONFLICT OF INTEREST}

The authors have declared that this work involves no conflict of interest.

\section{AUTHORS' CONTRIBUTIONS}

Alberto Pardo Ibáñez: Data download and analysis, document writing.. Joaquín Madera Gil: Data download and analysis, document writing.

Maria Teresa Pellicer Chenoll: Data download and analysis, document writing.

\section{FUNDING}

This work was carried out with the support of the Department of Physical Education and Sport, Universidad de Valencia.

\section{HOW TO CITE}

PARDO IBÁÑEZ, Alberto; MADERA GIL, Joaquín. PELLICER CHENOLL, Maite; Bibliometric Study of Scientific Production on Handball. Movimento, v. 26, p. e26068, jan./dez. 2020. Available at: https://seer.ufrgs.br/Movimento/article/ view/101908. Accessed on: Sep. 19, 2020. DOI: https://doi.org/10.22456/1982$\underline{8918.101908}$

\section{EDITORIAL BOARD}

Alex Branco Fraga*, Elisandro Schultz Wittizorecki*, Ivone Job*, Mauro Myskiw*, Raquel da Silveira*

*Universidade Federal do Rio Grande do Sul, Escola de Educação Física, Fisioterapia e Dança, Porto Alegre, RS, Brasil 